(c) 2008 Elsevier B.V. All rights reserved.

\title{
A deterministic population dynamics model to study the distribution of a benthic bivalve with planktonic larvae (Paphia rhomboïdes) in the English Channel (NW Europe)
}

\author{
Marie Savina ${ }^{a,{ }^{*}}$ and Alain Ménesguen ${ }^{a}$ \\ aIFREMER, Centre de Brest, Département DYNECO, BP 70, 29280 PLOUZANE, France \\ *: Corresponding author : Marie Savina, email address : marie@niyelopell.com
}

\begin{abstract}
:
This paper describes the development of a modelling framework to study the distribution in the English Channel of a benthic bivalve with planktonic larvae, Paphia rhomboïdes. Age-structured population dynamics and growth models are linked together to a compartmental transport and NPZ (NutrientsPhytoplankton-Zooplankton) model. Used in a spin-up mode, i.e. with identical environmental forcing from a year to the next, this deterministic model converges to the same steady state whatever the initial conditions, after 15-30 years of simulation. Important features of the P. rhomboïdes distribution are reproduced, particularly its high abundance in the GNB (Golfe Normand-Breton) and its almost complete absence in the Western Channel. The results are discussed in relation with the modelling strategies, especially with regard to the advantages and drawbacks which could result from changing the box-model approach into a fine 3D hydrodynamic approach.
\end{abstract}

Keywords: English Channel; Paphia rhomboïdes; Population dynamics model; Growth model; Meroplanktonic invertebrates; Spatial distribution 


\section{Introduction}

The English Channel (NW Europe) is remarkable for the abundance and diversity of its benthos (Holmes, 1966; Cabioch et al., 1977). Among the main listed bivalves, the banded carpet shell (Paphia rhomboïdes) is particularly widespread in the region, and one of the most abundant species in terms of biomass (Holme, 1966; Retière, 1979; Blanchard, 1982; Blanchard et al., 1983) in the "Golfe Normand-Breton", in the central part of the Channel (Fig.1). It is an infaunal filter-feeding bivalve, which is targeted by the trawling shellfish fishery existing in the "Golfe Normand-Breton" (Berthou, 1985, 1987 and 1989; Noël et al. 1995). In addition to its wide distribution and its halieutic interest, extensive scientific data has been collected describing its distribution, biology and ecology (Holme, 1966; Cabioch, 1968; Lucas, 1969; Chassé and Glémarec, 1973; Gentil, 1976; Glémarec and Bouron, 1978; Retière, 1979; Blanchard, 1982; Blanchard et al., 1983 and 1986 a and b; Morvan, 1987; Morin 1998), which make this species of particular interest for studying the determinism of the distribution of benthic invertebrates in the English Channel.

Many marine benthic invertebrates are meroplanktonic species, which means that their life cycle includes a planktonic larval phase, prior to the bottom-dwelling juvenile and adult phase. To understand and predict changes in space- and time distributions of these invertebrates, it is important to consider the relative influence of the different processes affecting planktonic and benthic phases, and beneficial to include them both in a common modelling framework (Roughgarden et al., 1988; Eckman, 1996). Such models however are not common (Possingham and Roughgarden, 1990; Dekshenieks et al., 2000; Klinck et al., 2002), while population dynamic models of the benthic stage alone are (e.g.: McArdle et al., 1997; Solidoro et al., 2003; Gangnery et al., 2004). On the other hand, extensive work has been done on the modelling of larval stage alone (for example: Young et al., 1998; Ellien et al., 2004; Condie et al., 2006, etc...).

Numerous processes potentially leading to the space and time distribution of populations through differential mortality are related to the nutrition state, growth or size of the benthic phase: physiological stress, predation, trophic competition, sensitivity to mechanical perturbation. This suggests the interest of coupling a population dynamic model to an ecophysiological model, in order to simulate a least a part of the mortality, instead of forcing it. Dekshenieks et al (2000) had such an approach when developing a size-structured model for the Eastern oyster, where weight gain or loss controls the transfer of individuals between size classes, the mortality rate decreasing gradually from the smallest to the biggest size-class. The literature about the modelling of filterfeeding bivalve's growth is abundant (for example: Bensch et al., 1991; Raillard et al., 1993; Kobayashi et al., 1997; Campbell and Newell, 1998; Grant and Bacher, 1998; Scholten and Smaal, 1998; Pouvreau et al., 2000 a; Solidoro et al., 2000; Ren and Ross, 2001; Hawkins et al., 2002)

The present study is part of a research project focused on the study of the distribution of $P$. rhomboïdes, which uses a modelling framework to describe realistically the two life stages of the species and, as much as possible, the processes leading to the distribution pattern of the bivalve populations.

A simple growth model has been developed for P. rhomboïdes, and implemented for the English Channel area (Savina and Ménesguen, in press). This work has suggested the important influence of the growth-related processes on the distribution of the species: particularly, the extremely low growth obtained with the model in the Western Channel can explain the almost complete absence of the species in this area.

The present article describes the coupling of the previously mentioned growth model to an agestructured population dynamic model, as well as to an existing spatial "Nitrate-PhytoplanktonZooplankton-Detritus" (NPZD) model. The obtained modelling framework as is used in stable annual environmental conditions to reproduce the observed species distribution, and the modelling options are discussed in relation with the obtained results. 


\section{Material and methods}

\subsection{Available data}

\subsubsection{P. rhomboïdes distribution}

Two maps of $P$. rhomboïdes distribution in the English Channel are available. Holmes (1966) established a semi-quantitative one with the results of the benthos study that he realized in the sixties, with an extensive sampling of the English and French coastal zones as well as some transects in the central area. In the seventies, another benthos study was carried out by Cabioch, Glaçon, and Retière (personal communication, 2002) that allows establishing an "occurrenceabsence" map on the whole Channel Sea this time.

\subsection{2. $P$. rhomboïdes demography and growth}

Individuals of $P$. rhomboïdes were collected in the different areas of the "Golfe Normand-Breton" (GNB) during four cruises: BENTHOMONT I and II (April 2002), BIVALVES I and II (May 2002). (Savina, 2004). The age of all animals was determined, and a part of them were weighted (Savina and Ménesguen, in press; Savina, 2004), in order to obtain population structures and instantaneous growth curves in different parts of the GNB.

The sampling strategy has been designed to assess the growth and demography of some local populations rather than to evaluate the species abundance in the whole GNB area. However, the sampling in the subtidal part of the "Baie du Mont Saint-Michel" was sufficient to estimate reasonably the average abundance in this area.

\subsection{The model}

\subsubsection{The transport and NPZD sub-models}

A transport box-model was developed for the English Channel (Ménesguen and Hoch 1997) and was coupled to a biogeochemical planktonic (or NPZD) model (Hoch 1998), thanks to the ELISE software (Ménesguen 1991).

The English Channel has been divided into 71 boxes (Fig. 1) and water fluxes between them have been calculated automatically from a pre-established map of tidal residual currents in the Channel available on a 1 mile grid (Salomon and Breton, 1993). A 2-layer, vertical thermohaline model is linked with the horizontal circulation scheme, in order to simulate thermal and/or haline stratification.

The NPZD model is based on nitrogen biogeochemical cycle but also simulates phosphorus, silicon and carbon ones, according to a constant stoichiometry in uptake by phytoplankton. The planktonic system is described with the help of three autotrophic and two heterotrophic compartments, as well as two detrital and four mineral compartments, both in the water column and the sediment (Hoch, 1998).

\subsubsection{The $P$. rhomboïdes sub-models}

The population dynamics sub-model (Fig. 2)

The benthic adult population is split into 12 annual age classes, each of them being divided into 2 cohorts corresponding to two main spawning periods. In every box of the Channel model, each cohort in each age class is described by its abundance (ind. $\mathrm{m}^{-2}$ ) and its mean individual soft bodies weight (Ash Free Dry Weight or AFDW, mg).

The abundance in each age class depends on (1) recruitment (ie: arrival of individuals from the previous age class), (2) mortality and (3) aging (ie: departure of individuals to the next age class). 
The larval pelagic population is split into 2 days long age classes, each of them being described by the larval abundance in the sea water $\left(\right.$ ind. $\left.\mathrm{m}^{-3}\right)$. The abundance in each age class depends on the same processes as for benthic classes (recruitment, mortality and aging), but it also depends on (1) horizontal fluxes between the different boxes due to advection and dispersion, (2) vertical fluxes (a) between surface- and bottom water layers (in stratified areas) due to diffusion and sedimentation of larvae, (b) between the bottom water layer and the sediment layer due to the sedimentation of the larvae (Fig. 3).

The biological equations are presented in the Tables 1 and 2 .

The growth sub-model and the coupling

A relatively simple deterministic growth model was developed for $P$. rhomboïdes to calculate the individual soft body ash free dry weight along the whole benthic life. Without any dynamic coupling, it has been run over the whole English Channel (box after box), using the outputs of the NPZD model previously mentioned as food inputs (Savina and Ménesguen, in press).

The coupling is detailed in Fig. 4. The links between the three sub-units stay in: (1) the relationship between mortality rate and fecundity of the shellfishes and their growth performance; (2) the control of the planktonic resources as well as larvae abundance by the shellfish filtration.

In the following text, the whole modelling framework (transport - NPZD - population dynamics growth) will be referred to as "the model", or as "the fully coupled model" when the obtained results are compared to those of the growth model alone, i.e. the "forced growth model".

\subsubsection{Running the fully coupled model and processing the results}

The model is used in a spin-up mode, i.e. the environmental forcing is set identical from one year to the next. Despite some non-linear components, this deterministic model revealed to have a stable point attractor, that is to say that it converges to the same steady state whatever the initial conditions, and its transitory regime does not exceed 30 years. The results presented in this paper were obtained considering a uniform initial condition of 10 four years old individuals per square meters in every benthic box of the model, and a 15 years long simulation. All the results presented correspond to the $15^{\text {th }}$ year of simulation: the growth results are shown during the spring period (julian day 115) for which data were available; the demographic results are presented in autumn (julian day 320), when the recruitment and aging processes of the year are finished. The population distribution maps presented here were all obtained considering only the individuals aged of 2 years and more (our experimental results suggested that the younger individuals were probably not properly sampled, Savina, 2004). Abundance and growth classes were defined in order to summarize and compare the results (model-data or model-model).

\subsubsection{Sensitivity analyses}

Seven alternative parameterizations were tested (Table 3). The final population distribution was used to assess the model's sensitivity: a sensitivity index was calculated for each parameterization on the basis of the differences observed in each box between the results of the tested parameterization and the original (nominal) parameterization.

$I_{p}=\sum_{i=1}^{71}\left|C_{N, i}-C_{p, i}\right|$

I: sensitivity index, p: tested parameterization, i: box number, C: abundance class, N: nominal simulation.

A sensitivity index per box was also calculated:

$I_{i}=\sum_{p=1}^{7}\left|C_{N, i}-C_{p, i}\right|$ 
I: sensitivity index, p: tested simulation, i: box number, C: abundance class, N: nominal simulation.

\section{Results}

\subsection{Confrontation with the available data}

\subsubsection{In the whole English Channel}

The steady state of the adult spatial distribution (benthic individuals aged of 2 years and more) is compared with the occurrence map from Cabioch et al. (pers. comm., Fig. 5).

From a qualitative point of view, the model reproduces reasonably well (1) the occurrence of the species in the GNB, in the central part of the Channel, as well as in a vast region in the southern part of the eastern Channel, (2) its almost complete absence from the western part of the English Channel. However, the model fails to predict: (1) the absence of $P$. rhomboïdes in some regions: mainly in the Great West Bay, off the Isle of Wight, in the eastern Bay of Seine, and in most of the extreme east of the English Channel; (2) the occurrence of the species off northern Brittany.

In order to build a more quantitative assessment of the model-data agreement, the presence-absence map, which is on a finer scale than our model, has been first degraded to the box-model scale: $P$. rhomboïdes has been considered as absent from a box if it is absent from all the squares contained in the box, and present otherwise. Then, boxes have been sorted into 8 abundance classes on the basis of the model results shown on Fig. 5, and the percentage of boxes really hosting $P$. rhomboïdes has been calculated for each abundance class (Fig. 6). The frequency of the bivalve real occurrence generally increases with the abundances predicted by the model (Fig. 6) until the $5^{\text {th }}$ abundance category. Above, the correlation becomes negative mainly because the model predicts high abundances of $P$. rhomboïdes in the regions of the Bay of Seine and the Bay of Somme, when it is really absent.

\subsubsection{In the "Golfe Normand-Breton"}

During the spring 2002, the mean abundance in the subtidal part of the "Baie du Mont SaintMichel" was 5 ind. $\mathrm{m}^{-2}$. In the corresponding box, the steady state model predicts an abundance of 113 ind. $\mathrm{m}^{-2}$, if all age classes are summed, or 6 ind. $\mathrm{m}^{-2}$ aged of two years or more, in spring. It was explained above why we think that it is more reasonable to compare the abundance data with the abundances obtained with the model for "adult" age classes only. If only 2-years and older age classes are considered, observed and simulated steady state demographic structures in the box "Baie de Saint-Brieuc" look similar (Fig. 7), but annual mortality rate is slightly underestimated by the model $\left(0.4 \mathrm{y}^{-1}\right.$ vs $0.57 \mathrm{y}^{-1}$ in data).

\subsection{Model's behaviour and properties}

\subsubsection{Influence of growth in the nominal simulation}

The geographic variability of asymptotic individual weight obtained with the fully coupled model is much lower than the one previously obtained with the growth model forced by the simulated environmental variables (Fig. 8). This is due mainly to the truncation of the high values produced by the forced growth model: except in the western Channel (where low asymptotic individual weights differ only a little from the growth model alone to the fully coupled model), the asymptotic individual weights are limited around $500 \mathrm{mg}$ (AFDW soft bodies) with the fully coupled model. However, the population abundance results obtained with this fully coupled model clearly reflect the variability in growth conditions previously identified by the growth model alone (Fig. 9). Thus, $P$. rhomboïdes abundance, as determined by the fully coupled model, appears to be closely related to the growth possibilities computed by the growth model alone (Fig. 10). 


\subsubsection{Sensitivity analyses}

Five parameters were tested (table 3): four of them describe the physical and biological properties of larvae, and the last one is one parameter of the equation linking growth and mortality. Either higher values or/and smaller values (around respectively $150 \%$ and $50 \%$ of the reference value) were tested. The results are clearly more sensitive to the relationship between weight and mortality rate in the benthic stage than to any of the investigated larvae-related parameters (table 4). Within those, the larval mortality rate was the most sensitive.

As far as the geographic distribution is concerned, the Fig. 11 clearly indicates the robustness of the results in the South-West English Channel: the bivalve is absent in all the tested cases. The NorthWest and central regions are the most sensitive, for all the parameters. 


\section{Discussion}

This model reproduces important features of the $P$. rhomboïdes distribution in the English Channel, and particularly its high abundance in the GNB as well as in the south of the Eastern Channel, along with its almost complete absence in the Western Channel. These results suggest the dominance of the food resources factor to explain the distribution of this species at the scale of the continental sea, with a generally longitudinal partition between the poor Western Channel and the rich mid- and Eastern Channel. The abundances obtained with the model are of the same magnitude as the observed abundances of $P$. rhomboiddes as far as the data allowed us to compare. However, this model has not been designed to fully explain the bivalve distribution: neither the spatial competition with the rest of the endofauna, the predation, nor the trophic competition with the rest of the filterfeeders is considered in this single species model. Besides, given the spatial resolution of the model and the available data, it is not possible to calculate reliable estimation of observed mean abundance per box (except in one, see 2.1.2).

With a mechanistic approach, we tried to include in our model all the processes leading to the distribution of filter-feeding bivalves having pelagic larvae, and to reduce the forcing to the minimum. However, the characteristics of the transport sub-model as well as the available data had to be considered when choosing the complexity level adopted for the formulation of processes: (1) the larval transport and recruitment was kept simple, in accordance with the spatial resolution of the transport sub-model and its basic representation of the hydrodynamics; (2) the growth sub-model was simple as well, because of the few available data to parameterize it.

$P$. rhomboïdes lives in soft sediments, ranging from sand to gravel (Holme, 1966; Cabioch, 1968; Retière, 1979). The benthic habitat for the adult stage is usually imposed in the existing population dynamics models. The recruitment of larvae is limited to the appropriate substrate, i.e.: where the studied species is known to live (Possingham and Roughgarden, 1990; Klinck et al., 2002). In this model, we tried to include the processes leading to the recruitment and survival of the species in particular habitats. Thus, in the model, the deposition of larvae on the bottom is controlled by the hydrodynamics in the bottom water layer (ie: the bottom roughness). This approach will be really meaningful when the population dynamics model will be coupled to a full $3 \mathrm{D}$ hydrodynamic submodel, although the box-model already allows restraining the settlement of $P$. rhomboides in the central Channel, where effectively cobble and boulders are dominant. On the other hand, this species is also absent from fine sediments (silts, mud and fine sands) where the hydrodynamics certainly allow the larvae to reach the bottom. The instability of mud could probably prevent the settlement of juveniles, and high turbidity could alter their nutrition and respiration. Only the effect of turbidity on nutrition is considered in the model, and it does not prevent the development of populations in fine sediments habitats (ex: "Baie of Seine"), from where the species is actually absent.

Mortality (a part of) and fecundity are calculated in the model as a function of individual weight. The fecundity is traditionally expressed as a function of individual size (Urrutia et al., 1999; Pouvreau et al., 2000; Héral et Deslous-Paoli, 1983). Concerning the mortality, the relation to the weight allowed considering the greater vulnerability of small individuals (low reserves, low mechanical protection). This formulation is also linked to the modelling of the intra-specific competition: too many individuals cause a food depletion (diatoms and particulate organic detritus from the primary production model), and therefore a lower growth, and a higher mortality. Not surprisingly, the sensitivity analysis performed indicates that the influence of the weight in the mortality rate calculation is critical. In their weight-structured oyster population dynamics model, Dekshenieks et al (2000) had a similar approach, using a decreasing mortality rate from the smallest to the biggest weight class. 
Others aspects would be interesting to develop in the future: (1) Predation (e.g.: crabs, sea star) is considered as an important population structuring factor (Olafsson et al., 1994; Seitz et al., 2001; Beal et al., 2001). (2) Inter-specific trophic competition. Dekshenieks et al (2000) addressed both predation and trophic competition, by considering the feeding rate of oyster's main competitor as well as the feeding rates of two significant predators, as functions of temperature, salinity, and predators and competitor abundance (prescribed constant distribution). The impact of the competitor is however limited, since food is a prescribed input in the model as opposed to a dynamically evolving distribution including coupling with the oyster and competitor population. (3) Spatial competition. The filter-feeding endofauna must be able to move in the sediment to maintain an appropriate position for the ventilation, as well as to avoid predators and physical stress (Brenchley, 1982). In particularly favourable areas (i.e.: where food is not limiting), the space could thus be the factor limiting the filter-feeders abundance. The adult-larvae interactions are already included in this model, since the benthic individuals can filter their own larvae.

To our knowledge, this model is the first marine invertebrate population dynamics model which includes both pelagic larval stage and benthic adult stage, and with an explicit coupling between the demographic sub-model (adults), the growth sub-model and the NPZD sub-model on one hand, and between the demographic sub-model (larvae) and the transport sub-model on the other hand.

Given the wide distribution of the studied species, it was interesting to consider the whole English Channel in this study. The low spatial resolution as well as the simplicity of the hydrodynamic model allowed the realisation of hundreds of 20 to 50 years long simulations during the development and calibration of this population dynamics model. The results have been satisfying in terms of reproducing the main features of $P$. rhomboïdes distribution at this scale. Still, the next step will be to transfer the population dynamics (and growth model) to a recently developed finegridded 3D hydrodynamic and biogeochemical model (Ménesguen et al., 2006). This will allow us to: (1) Confirm the results obtained at large scale. The existing model probably understates the importance of the pelagic larval stage in the distribution, mainly because it overestimates the larval dispersion. Thus, a confirmation of the dominance of the growth-related processes in the distribution of $P$. rhomboïdes in the English Channel will be aimed at, with a more balanced pelagobenthic model. (2) Refine and improve the results on a finer scale. A finer spatial resolution would benefit both to the representation of the food resources -off the North French Brittany coast, where the model predicts the absence of the species due to the poor food supply, small and widespread populations occur, probably in relation with a locally higher primary production sustained by the terrestrial input and the strong vertical mixing- ; and to the representation of the larval transport and recruitment -small and widespread populations occur as well in the central part of the Channel, probably in relation with the local decrease of the bottom currents in some sheltered zones. Finally, a finer resolution will also benefit to the study of some particular areas such as the "Golfe Normand-Breton" where most of the fishing occurs.

\section{Acknowledgements}

This work was supported by IFREMER and Région Bretagne funding. Thanks to L. Cabioch for his unpublished data about the distribution of $P$. rhomboïdes in the English Channel. BENTHOMONT cruises have been funded by the PNEC (Programme National Environnement Côtier) "Baie du Mont Saint-Michel". 


\section{References}

Beal, B.F., Parker, M.R., Vencile, K.W., 2001. Seasonal effects of intraspecific density and predator exclusion along a shore-level gradient on survival and growth of juveniles of the soft-shell clam, Mya arenaria L., in Maine, USA. J. Exp. Mar. Biol. Ecol. 264, 133-169.

Bensch, A., Bacher, C., Baud, J.P., Martin, J.L., 1991. Modélisation de la croissance de Ruditapes philippinarum dans un système expérimental. Haliotis, 13 71-82.

Berthou, P., 1985. Etude des praires et des bivalves associés en Bretagne nord. Rapport intermédiaire CRUSCO, 10 pp.

Berthou, P., 1987. Note interne concernant la mise en valeur des bivalves autres que les pectinidés, $27 \mathrm{pp}$.

Berthou, P., 1989. Note interne sur l'exploitation des petits bivalves, $27 \mathrm{pp}$.

Blanchard, M., 1982. Peuplement des sables grossiers. In: Etude écologique d'avant-projet du site marémoteur du golfe Normand-Breton: Le benthos subtidal. Rapport final EDF/CNEXO/MNHN, Brest, pp. 35-67.

Blanchard, M., Chardy, P., Dreves, L., Guennegan, Y., 1983. Les Bivalves. In : Etude écologique du site Cotentin centre. Volume 3: Le subtidal. Rapport CNEXO/EDF, Brest, $150 \mathrm{pp}$.

Blanchard, M., Morvan, C., Quiniou, F., 1986 a. Dynamique de population de la palourde rose Tapes rhomboïdes (Pennant, 1977) dans le golfe Normand-Breton. Haliotis 15, 91-101.

Blanchard, M., Piriou, J.Y., Berthou, P., Morvan, C., Quiniou, F., Chardy, P., Retière, C., Heliez, A., Le Calvez, J.C., 1986 b. Le benthos subtidal. Tome 3 de l'Etude Régionale Intégrée du Golfe Normand-Breton. Rapport IFREMER-DERO-86.27-EL, Brest, 100 pp.

Brenchley, G.A., 1982. Mechanisms of spatial competition in marine soft-bottom communities. J. Exp. Mar. Biol. Ecol. 60, 17-33.

Cabioch, L., 1968. Contribution à la connaissance des peuplements benthiques de la Manche Occidentale. Cah. Biol. Mar., IX (5), 720 pp.

Cabioch, L., Gentil, F., Glaçon, R., Retière, C., 1977. Le macrobenthos des fonds meubles de la Manche : Distribution générale et écologie. In: Keegan B.F., Ceidigh P.O., Boaden P.J.S. (Editors), Biology of benthic organisms: $11^{\text {th }}$ European Symposium on Marine Biology, Galway, October 1976. Pergamon Press Oxford, UK, pp. 115-128.

Cabioch, L., Glaçon, R., and Retière, C., 2002. Maps of the qualitative distribution of Paphia rhomboïdes adn Glycymeris glycymeris in the English Channel. Personal communication.

Campbell, D.E. and Newell, C.R., 1998. MUSMOD, a production model for bottom culture of the blue mussel, Mytilus edulis L. J. Exp. Mar. Biol. Ecol. 219, 171-203.

Chassé, C. and Glémarec, M., 1973. Les bancs de Venerupis rhomboïdes des Glénans. Fac. Sci. Brest. Rapport contrat CNEXO 72/527, 30 pp.

Condie, S.A., Mansbridge, J.V., Hart, A.M., Andrewartha, J.R., 2006. Transport and recruitment of silver-lip pearl oyster larvae on Australia's North West Shelf. J. Shellfish Res. 25 (1), 179-185.

Dekshenieks, M.M., Hofmann, E.E., Klinck, J.M., Powell, E.N., 2000. Quantifying the effects of environmental change on an oyster population: a modeling study. Estuaries 23 (5), 593-610.

Eckman, J.E., 1996. Closing the larval loop: linking larval ecology to the population dynamics of marine benthic invertebrates. J. Exp. Mar. Biol. Ecol. 200, 207-237.

Ellien, C., Thiébaut, E., Dumas, F., Salomon, J.C., Nival, P., 2004. A modelling study of the respective role of hydrodynamic processes and larval mortality on larval dispersal and recruitment of benthic invertebrates: example of Pectinaria koreni (Annelida: Polychaeta) in the Bay of Seine (English Channel). J. Plankton Res. 26 (2), 117-132.

Gangnery, A., Bacher, C., Buestel, D., 2004. Modelling oyster population dynamics in a Mediterranean coastal lagoon (Thau, France): sensitivity of marketable production to environmental conditions. Aquaculture 230: 323-347. 
Gentil, F., 1976. Distribution des peuplements benthiques en baie de Seine. Thèse de doctorat de l'université de Paris VI, France, 250 pp.

Glémarec, M. and Bouron, D., 1978. Evolution de la maturité sexuelle chez six espèces de bivalves des Glénan. Haliotis 9 (1), 45-48.

Grant, J. and Bacher, C., 1998. Comparative models of mussel bioenergetics and their validation at field culture sites. J. Exp. Mar. Biol. Ecol. 219, 21-44.

Hawkins, A.J.S., Duarte, P., Fang, J.G., Pascoe, P.L., Zhang, J.H., Zhang, X.L., Zhu, M.Y., 2002. A functional model of responsive suspension-feeding and growth in bivalve shellfish configured and validated for the scallop Chlamys farreri during culture in China. J. Exp. Mar. Biol. Ecol. 281, 1340.

Héral, M. and Deslous-Paoli, J.M., 1983. Energetic value of the tissue of the oyster Crassostrea gigas estimated by microcalorimetric measures and by biochemical evaluation. Oceanol. Acta 6 (2), 193-199.

Hoch, T., 1995. Modélisation du cycle biogéochimique des éléments limitant la production biologique en Manche (N, P, Si). Thèse de doctorat de l'université de Paris VII, 205 pp.

Hoch, T., 1998. Modélisation du réseau trophique pélagique et de la production primaire en Manche. Oceanol. Acta 21, 871-885.

Holme, N.A., 1966. The bottom fauna of the English Channel. Part II. J. Mar. Biol. Assoc. UK 46, 401-493.

Klinck, J.M., Hofmann, E.E., Powell, E.N., Dekshenieks, M.M., 2002. Impact of channelization on oyster production: a hydrodynamic-oyster population model for Galveston Bay, Texas. Envir. Model. Assess. 7, 273-289.

Kobayashi, M., Hofmann, E.E., Powell, E.N., Klinck, J.M., Kusaka, K., 1997. A population dynamics model for the Japanese oyster, Crassostrea gigas. Aquaculture 149: 285-321.

Lucas, A., 1969. Remarques sur l'hermaphrodisme juvénile de quelques Veneridae (Bivalvia). Malacologia 9 (1), 275-276.

McArdle, B.H., Hewitt, J.E., Thrush, S.F., 1997. Pattern from process: it is not as easy as it looks. J. Exp. Mar. Biol. Ecol. 216, 229-242.

Ménesguen, A., 1991. "ELISE", an interactive software for modelling complex aquatic ecosystems. In: Arcilla A.S., Pastor M., zienkiewicz O.C. and Schrefler B.A. (Editors), 1991. Computer Modelling in Ocean Engineering. Balkema, Rotterdam, pp. 87-94.

Ménesguen, A. and Hoch, T., 1997. Modelling the biogeochemical cycles of elements limiting primary production in the English Channel. I. Role of thermohaline stratification. Mar. Ecol. Prog. Ser. 146, 173-188.

Ménesguen, A., Cugier, P., Loyer, S., Vanhoutte-Brunier, A., Hoch, T., Guillaud, J.F., Gohin, F., 2006. Two- or three-layered box-model versus fine 3D models for coastal ecological modelling? A comparative study in the English Channel (Western Europe). J. Mar. Systems, in press.

Mileikovsky, S.A., 1973. Speed of active movement of pelagic larvae of marine bottom invertebrates and their ability to regulate their vertical position. Mar. Biol. 23, 11-17.

Morin, J., 1998. Prospection et évaluation des stocks de «petits bivalves » en Manche Est. Potentialités d'exploitation. Rapport interne DRV/RH/RST/98-13, Port en Bessin, 84 pp.

Morvan, C., 1987. Cycle de reproduction et fécondité de deux espèces de bivalves dans le golfe Normand-Breton. Thèse de doctorat de l'université de Bretagne occidentale, France, 138 pp.

Noël, P., Blanchard, M., Berthou, P., 1995. Cartographie et évaluation des principaux mollusques filtreurs du golfe Normand-Breton. Rapport interne DEL-DRV/RH /95.11, Brest, 31 pp.

Olafsson, E.B., Peterson, C.H., Ambrose, W.G., 1994. Does recruitment limitation structure populations and communities of macro-invertebrates in marine soft sediments: the relative significance of pre- and post-settlement processes. Oceano. Mar. Biol.: an annual review 32, 65109. 
Paulet, Y.M., Bekhadra, F., Devauchelle, N., Donval, A., Dorange, G., 1997. Cycles saisonniers, reproduction et qualité des ovocytes chez Pecten maximus en rade de Brest. Ann. Inst. Oceanogr. Paris 73 (1), 101-112.

Possingham, H.P., Roughgarden, J., 1990. Spatial population dynamics of a marine organism with a complex life cycle. Ecology 71 (3), 973-985.

Pouvreau, S., Bacher, C., Héral, M., 2000 a. Ecophysiological model of growth and reproduction of the black pearl oyster, Pinctada margaritifera: potential applications for pearl farming in French Polynesia. Aquaculture 186, 117-144.

Pouvreau, S., Gangnery, A., Tiapari, J., Lagarde, F., Garnier, M., Bodoy, A., 2000 b. Gametogenic cycle and reproductive effort of the tropical blacklip pearl oyster, Pinctada margaritifera (Bivalvia: Pteriidae), cultivated in Takapoto atoll (French Polynesia). Aquat. Living Resour. 13 (1), 37-48.

Raillard, O., Deslous-Paoli, J.M., Héral, M., Razet, D., 1993. Modélisation du comportement nutritionnel de Crassostrea gigas dans le bassin de Marennes-Oléron. Oceanol. Acta 16, 73-82.

Ren, J.S. and Ross, A.H., 2001. A dynamic energy budget model of the Pacific oyster Crassostrea gigas. Ecol. Model. 142, 105-120.

Roughgarden, J., Gaines, S., Possingham, H., 1988. Recruitment dynamics in complex life cycles. Science, 241 1460-1466.

Retière, C., 1979. Contribution à la connaissance des peuplements benthiques du Golfe NormandBreton. Thèse de doctorat de l'université de Rennes, France, 421 pp.

Salomon, J.C. and Breton, M., 1993. An atlas of long term currents in the Channel. Oceanologica Acta 16, 439-448.

Savina, M., 2004. Modélisation écologique des populations de palourdes roses (Paphia rhomboüdes) et d'amandes de mer (Glycymeris glycymeris) en Manche. Thèse de doctorat de l'université d'Aix-Marseille II, France, $191 \mathrm{pp}$.

Savina, M. and Pouvreau, S., 2004. A comparative ecophysiological study of infaunal filter-feeding bivalves Paphia rhomboïdes and Glycymeris glycymeris. Aquaculture 239, 289-306.

Savina, M., Ménesguen, A., in press. The growth of the banded carpet shell (Paphia rhomboïdes) in a contrasted region, the English Channel (Western Europe): a modelling study. Ecological modelling.

Scholten, H. and Smaal, A.C., 1998. Responses of Mytilus edulis L. to varying food concentrations: testing EMMY, an ecophysiological model. J. Exp. Mar. Biol. Ecol. 219, 217-239.

Seitz, R.D., Lipcius, R.N., Hines, A.H., Eggleston, D.B., 2001. Density-dependent predation, habitat variation, and the persistence of marine bivalves prey. Ecology 82 (9), 2435-2451.

Solidoro, C., Pastres, R., Melaku Canu, D., Pellizzato, M., Rossi R., 2000. Modelling the growth of Tapes philippinarum in Northern Adriatic lagoons. Mar. Ecol. Prog. Ser. 199, 137-148.

Solidoro, C., Melaku Canu, D., Rossi, R., 2003. Ecological and economic considerations on fishing and rearing of Tapes phillipinarum in the lagoon of Venice. Ecol. Model. 170, 303-318.

Urrutia, M.B., Ibarrola, I., Iglesias, J.I.P., Navarro, E., 1999. Energetics of growth and reproduction in a high-tidal population of the clam Ruditapes decussatus from Urdaibai Estuary (Basque Country, N. Spain). J. Sea Res. 42, 35-48.

Young, E.F., Bigg, G.R., Grant, A., Walker, P., Brown, J., 1998. A modelling study of environmental influences on bivalve settlement in the Wash, England. Mar. Ecol. Prog. Ser. 172, 197-214. 


\section{Tables}

Table 1: Biological equations for reproduction and the larval stage.

REPRODUCTION
Female fecundity:
$L_{i}=t a .\left(W_{i}\right)^{t b}$
$F_{i, n}=f a_{n} \cdot L_{i}^{f b_{n}}-f c_{n} \cdot L_{i}{ }^{f d_{n}}$

$\mathrm{L}_{\mathrm{i}}$ : individual shell length for age class $\mathrm{i}(\mathrm{mm})$; ta et tb: weight-length relationship parameters;

$\mathrm{W}_{\mathrm{i}}$ : individual flesh AFDW for the age class $\mathrm{i}$;

$\mathrm{F}_{\mathrm{i}, \mathrm{n}}$ : individual total number of oocytes spawned by a female from age class $\mathrm{i}$, during the reproduction period $\mathrm{n}$;

$\mathrm{fa}_{\mathrm{n}}, \mathrm{fb}_{\mathrm{n}}, \mathrm{fc}_{\mathrm{n}}$ et $\mathrm{fd}_{\mathrm{n}}$ : fecundity-length relationship parameters for the reproduction period $n$.

Spawning:

For $\mathrm{td}_{\mathrm{n}} \leq \mathrm{t} \leq \mathrm{tf}_{\mathrm{n}}$,

$O E_{n}(t)=\sum_{i=a}^{b} \operatorname{frep}_{n}(t) \times X_{i}(t) \times F_{i, n} \times S R$

$\operatorname{frep}_{\mathrm{n}}(\mathrm{t})=\frac{1}{\sigma_{T, \mathrm{n}} \times \sqrt{2 \times \pi}} \times \exp \left(-\frac{\left(\mathrm{t}-\mathrm{tmax}_{\mathrm{n}}\right)^{2}}{2 \times \sigma_{T, n}{ }^{2}}\right)$

$\mathrm{OE}_{\mathrm{n}}(\mathrm{t})$ : oocytes produced at time $\mathrm{t}$ per $\mathrm{m}^{2}$ of substrate;

$\operatorname{td}_{n}$ and $\mathrm{tf}_{\mathrm{n}}$ : beginning and end of the reproduction period $\mathrm{n}$;

a: first age class where $\mathrm{W}_{\mathrm{i}} \geq \mathrm{W}_{\mathrm{R}}$;

$\mathrm{W}_{\mathrm{R}}$ : minimum flesh AFDW for reproduction;

b: last age class;

frep $_{n}(t)$ : spawning distribution function throughout the reproduction period $n$;

$\mathrm{X}_{\mathrm{i}}(\mathrm{t})$ : abundance for age class $\mathrm{i}$ (ind. $\mathrm{m}^{-2}$ );

SR: population sex-ratio;

$\operatorname{tmax}_{\mathrm{n}}$ : mean spawning date, corresponding to $(\mathrm{td}+\mathrm{tf}) / 2$;

$\sigma_{\mathrm{T}, \mathrm{n}}:$ standard deviation of spawning date.

\section{LARVAL LIFE}

Larvae are distributed into 24 age classes of 2 days each.

$\frac{\mathrm{dXL}_{\mathrm{i}}(\mathrm{t})}{\mathrm{dt}}=\mathrm{rL}_{\mathrm{i}}(\mathrm{t})-\mathrm{vL}_{\mathrm{i}}(\mathrm{t})-\mathrm{XL}_{\mathrm{i}}(\mathrm{t}) \times \mathrm{mL}-\mathrm{XL}_{\mathrm{i}}(\mathrm{t}) \times \frac{\text { Filt }}{\mathrm{h}}+$ Fsed $(\mathrm{i})$

$\mathrm{XL}_{\mathrm{i}}(\mathrm{t})$ : larval abundance in the water column at time $\mathrm{t}\left(\right.$ ind. $\left.\mathrm{m}^{-3}\right)$; $\mathrm{mL}$ : larval mortality rate $\left(\mathrm{d}^{-1}\right)$;

$\mathrm{h}:$ thickness of the water layer under consideration $(\mathrm{m})$;

Filt: global filtration rate of benthos $\left(\mathrm{m}^{3} \cdot \mathrm{m}^{-2} \cdot \mathrm{d}^{-1}\right)$, depending on the $P$. rhomboïdes abundance in the sediment layer and the individual filtration rates calculated with the growth sub-model. Filt is equal to 0 for the surface water layer.

Aging:

$+1^{\text {st }}$ age class:

$\mathrm{rL}_{1}(\mathrm{t})=\mathrm{p}_{\mathrm{n}} \times \frac{\mathrm{OE}_{\mathrm{n}}(\mathrm{t})}{\mathrm{h}}$
$\mathrm{OE}_{n}(\mathrm{t})$ : number of ovocytes spawned in the sediment layer below (ov. ${ }^{-2}$ );

$\mathrm{p}_{\mathrm{n}}$ : hatching rate for the spawning period $\mathrm{n}$.

This occurs only in the bottom water layer.

+ General case

The transfer of individuals from an age class to another one takes place every 2 days during one time step ( 0.05 day), it begins from the oldest age class to the youngest one.

If $t \equiv 0(\bmod 2)$,

Departure from the age class i:

$v L_{i}(t)=-\frac{X L_{i}(t)}{d t}$

Arrival in the age class $\mathrm{i}$ :

$r L_{i}(t)=\frac{X L_{i-1}(t)}{d t}$

Otherwise $r L_{i}(t)=0$ and $v L_{i}(t)=0$

$\mathrm{XL}_{\mathrm{i}}(\mathrm{t})$ : larval abundance in age class $\mathrm{i}$ at time $\mathrm{t}$ (ind. $\mathrm{m}^{-3}$ ).

Larvae sedimentation:

If $\mathrm{i} \geq \mathrm{c}$,

$v i t S(i)=\frac{v a}{v b+e^{(v c .2 i+v d)}}$

vitS(i): larval sedimentation rate $\left(\mathrm{m}^{-\mathrm{d}^{-1}}\right)$;

c: age class from which larvae start to have a downward motion;

va, vb, vc and vd: parameters;

2i: maximum age of the larvae in age class i ( 2 days age classes)

Then,

In the surface water layer:

$\operatorname{Fsed}(\mathrm{i})=-\mathrm{XL}_{\mathrm{i}}(\mathrm{t}) \times \frac{\mathrm{vitS}(\mathrm{i})}{\mathrm{h}}$

In the bottom water layer:

Fsed $(\mathrm{i})=-\mathrm{XL}_{\mathrm{i}}(\mathrm{t}) \times \frac{\operatorname{vitS}(\mathrm{i})}{\mathrm{h}}+\mathrm{XL}_{\mathrm{i}} *(\mathrm{t}) \times \frac{\operatorname{vitS}^{*}(\mathrm{i})}{\mathrm{h}}$

Fsed(i): sedimentation flux for larvae of age class $\mathrm{i}$ (ind. $\mathrm{m}^{-3} \cdot \mathrm{d}^{-1}$ );

$\mathrm{XL}_{\mathrm{i}} *(\mathrm{t})$ : larval abundance for age class $\mathrm{i}$ in the surface water (ind. $\mathrm{m}^{-3}$ );

vitS*(i): larval sedimentation rate for the age class $\mathrm{i}$ in the surface water layer $\left(\mathrm{m} \cdot \mathrm{d}^{-1}\right)$. 
Table 2: Biological equations for the benthic life.

$$
\begin{aligned}
& \text { BENTHIC LIFE } \\
& \frac{\text { Abundance: }}{d X i(t)}=r A_{i}(t)-v A_{i}(t)-m A\left(W_{i}\right) \times X_{i}(t) \\
& \text { with } m A\left(W_{i}\right)=\frac{m a+m b \times e^{-m c \times W_{i}}}{365}
\end{aligned}
$$

$\mathrm{X}_{\mathrm{i}}(\mathrm{t})$ : abundance for the age class $\mathrm{i}$ at time $\mathrm{t}\left(\right.$ ind. $\left.\mathrm{m}^{-2}\right)$; $\mathrm{mA}\left(\mathrm{W}_{\mathrm{i}}\right)$ : mortality of adults $\left(\mathrm{d}^{-1}\right)$ depending on the individual AFDW;

$\mathrm{ma}, \mathrm{mb}$ and $\mathrm{mc}$ : parameters

Aging:

$+1^{\text {st }}$ age class: recruitment

If $\tau_{F} \leq \tau_{D}$,

$$
r A_{1}(t)=\sum_{i=c}^{d} X L_{i}(t) \times v i t S(i) \times\left(1-\frac{\tau_{F}}{\tau_{D}}\right)
$$

with $\tau_{F}=\rho \times\left(\frac{\mathrm{K}}{\ln \left(\frac{H}{z_{0}}\right)-1}\right)^{2} \times(\bar{U})^{2}$

Otherwise $r A_{1}(t)=0$

c: age class from which larvae start to have a downward motion;

$\mathrm{d}$ : last larvae age class;

$\mathrm{XLi}(\mathrm{t})$ : larval abundance for the age class $\mathrm{i}$ in the bottom water layer (ind. $\mathrm{m}^{-3}$ );

vitS(i): larval sedimentation rate (m. $\mathrm{d}^{-1}$, see table 1$)$ in the bottom water layer;

$\tau_{\mathrm{F}}$ : bottom shear stress $\left(\mathrm{N} \cdot \mathrm{m}^{-2}\right)$;

$\tau_{\mathrm{D}}$ : critical bottom shear stress $\left(\mathrm{N} . \mathrm{m}^{-2}\right)$;

$\rho$ : water density;

K: Von Karman's constant;

$\mathrm{H}$ : total water column thickness (m);
$\mathrm{Z}_{0}$ : bottom roughness;

$\overline{\mathrm{U}}$ : average current speed $\left(\mathrm{m} \cdot \mathrm{s}^{-1}\right)$.

+ General case:

The transfer of individuals from an age class to another one takes place every year during one time step $(0.05$ day), it begins from the oldest age class to the youngest one. It occurs before the recruitment period in order to avoid numerical dispersion (otherwise part of the newly recruited individuals could be transferred directly in the following age class).

$t_{t}=t_{n}-\left(3 \times \sigma_{T, n}+2\right)$

If $t \equiv t_{t}(\bmod 365)$,

Departure from the age class i:

$$
r A_{i}(t)=\frac{X_{i-1}(t)}{d t}
$$

Arrival in the age class $\mathrm{i}$ :

$$
v A_{i}(t)=-\frac{X_{i}(t)}{d t}
$$

Otherwise $r A_{i}(t)=0$ et $v A_{i}(t)=0$

$\mathrm{t}_{\mathrm{t}}$ : transfer date;

$t_{n}$ : average anniversary date of the recruitment for the cohort n.

$\sigma_{\mathrm{T}, \mathrm{n}}$ : spread around the date of maximum spawning.

Weight transfer:

It occurs in the same fashion than for individuals (aging):

$t_{t}=t_{n}-\left(3 \times \sigma_{T, n}+2\right)$

If $t \equiv t_{t}(\bmod 365)$

transfer: $W_{i}(t)=W_{i-1}(t)$

$\mathrm{t}_{\mathrm{t}}$ : transfer date;

$t_{n}$ : average anniversary date of the recruitment for the cohort n. 
Table 3: Parameter values. The parameters tested in the sensitivity analysis are written in italic.

\begin{tabular}{|c|c|c|c|c|}
\hline Parameters & Comments & Value & Unit & References \\
\hline $\mathrm{n}$ & Number of spawning periods & 2 & $\mathrm{y}^{-1}$ & Morvan, 1987 \\
\hline $\operatorname{td}_{1}$ & Beginning of the $1^{\text {st }}$ spawning period & 137 & \multirow{8}{*}{ julian days } & \multirow{8}{*}{ Estimated from Morvan, 1987} \\
\hline $\operatorname{tmax}_{1}$ & Mean spawning date (Gaussian max) & 149 & & \\
\hline$\sigma_{\mathrm{T} 1}$ & Standard deviation of $1^{\text {st }}$ spawning date & 4 & & \\
\hline & End of the $1^{\text {st }}$ spawning period & 161 & & \\
\hline $\operatorname{td}_{2}$ & Beginning of the $2^{\text {nd }}$ spawning period & 180 & & \\
\hline $\operatorname{tmax}_{2}$ & Mean spawning date (Gaussian max) & 225 & & \\
\hline$\sigma_{\mathrm{T} 2}$ & Standard deviation of $2^{\text {nd }}$ spawning date & 15 & & \\
\hline $\mathrm{tf}_{2}$ & End of the $2^{\text {nd }}$ spawning period & 270 & & \\
\hline $\begin{array}{l}\text { ta } \\
\text { tb }\end{array}$ & Weight-length relationship parameters & $\begin{array}{l}6.07 \\
0.3035\end{array}$ & $\begin{array}{l}\mathrm{mm} \cdot \mathrm{mg}^{-1} \\
\mathrm{~mm}\end{array}$ & Savina, 2004 \\
\hline $\begin{array}{l}\mathrm{fa}_{1} \\
\mathrm{fb}_{1} \\
\mathrm{fc}_{1} \\
\mathrm{fd}_{1} \\
\mathrm{fa}_{2} \\
\mathrm{fb}_{2} \\
\mathrm{fc}_{2} \\
\mathrm{fd}_{2}\end{array}$ & $\begin{array}{l}\text { Fecundity-length relationship parameters } \\
\text { for the } 1^{\text {st }} \text { spawning period }\end{array}$ & $\begin{array}{l}1.08 \times 10^{-15} \\
12.48 \\
9.20 \\
2.40 \\
3.57 \times 10^{-23} \\
17.58 \\
9.20 \\
2.40\end{array}$ & $\begin{array}{l}\text { w.mm } \\
\text { dimensionless }^{-1} \\
\text { w.mm } \\
\text { dimensionless } \\
\text { w.mm } \\
\text { dimensionless } \\
\text { w.mm } \\
\text { dimensionless }\end{array}$ & Morvan, 1987 \\
\hline $\mathrm{W}_{\mathrm{R}}$ & Minimum weight for reproduction & 200 & $\mathrm{mg}$ & \multirow[t]{2}{*}{$\begin{array}{l}\text { Estimated from Morvan, } 1987 \\
\text { and Savina, } 2004\end{array}$} \\
\hline b & $\begin{array}{l}\text { Number of age class for the benthic stage } \\
(1 \mathrm{yr} \text { each })\end{array}$ & 12 & dimensionless & \\
\hline SR & Sex-ratio & 0.5 & dimensionless & Morvan, 1987 \\
\hline $\mathrm{p}_{1}$ & Hatching rate for the $1^{\text {st }}$ spawning period & 0.2 & \multirow{2}{*}{ dimensionless } & \multirow{3}{*}{$\begin{array}{l}\text { Paulet et al., } 1997 \\
\text { (for Pecten maximus) }\end{array}$} \\
\hline $\mathrm{p}_{2}$ & Hatching rate for the $2^{\text {nd }}$ spawning period & 0.5 & & \\
\hline d & Number of age class for larvae (2days each) & 24 & dimensionless & \\
\hline$m L$ & Larval mortality rate & 0.5 & $d^{-1}$ & calibration \\
\hline $\mathrm{c}$ & $\begin{array}{l}\text { Age class from which larvae start to have } \\
\text { a downward motion }(9-10 \mathrm{j})\end{array}$ & 5 & dimensionless & calibration \\
\hline$v a$ & \multirow{4}{*}{ Parameters for the larvae sedimentation } & 100 & $m d^{-1}$ & \multirow{4}{*}{$\begin{array}{l}\text { Calibration } \\
\text { from Mileikovsky, } 1973\end{array}$} \\
\hline $\mathrm{vb}$ & & 1 & & \\
\hline $\mathrm{vc}$ & & -0.6 & dimensionless & \\
\hline $\mathrm{vd}$ & & 12 & & \\
\hline ma & \multirow{3}{*}{$\begin{array}{l}\text { Parameters of the weight-mortality } \\
\text { relationship }\end{array}$} & 0.3 & $\mathrm{yr}^{-1}$ & \multirow{3}{*}{ calibration } \\
\hline $\mathrm{mb}$ & & 2.5 & $\mathrm{yr}^{-1}$ & \\
\hline$m c$ & & 0.01 & $m g^{-1}$ & \\
\hline$\tau_{D}$ & $\begin{array}{l}\text { Critical bottom shear stress for larval } \\
\text { deposition }\end{array}$ & 3 & $N . m^{-2}$ & calibration \\
\hline $\mathrm{t}_{1}$ & $\begin{array}{l}\text { Average anniversary date of the recruitment } \\
\text { for the } 1^{\text {st }} \text { cohort }\end{array}$ & $149+21$ & \multirow{2}{*}{ Julian days } & \multirow{2}{*}{$\begin{array}{l}\text { Estimated from Morvan, } 1987 \\
\text { (average larval life of } 21 \text { days) }\end{array}$} \\
\hline $\mathrm{t}_{2}$ & $\begin{array}{l}\text { Average anniversary date of the recruitment } \\
\text { for the } 2^{\text {nd }} \text { cohort }\end{array}$ & $225+21$ & & \\
\hline$\rho$ & Water density & 1000 & $\mathrm{Kg} \cdot \mathrm{m}^{-3}$ & \multirow{3}{*}{ Hoch, 1995} \\
\hline K & Von Karman's constant & 0.4 & dimensionless & \\
\hline $\mathrm{Z}$ & Bottom roughness (uniform value for all boxes) & 0.0001 & $\mathrm{~m}$ & \\
\hline
\end{tabular}


Table 4: Investigated parameters and tested values for the sensitivity analyses.

\begin{tabular}{|c|c|c|c|c|c|}
\hline Simulations & $\begin{array}{l}\text { Larvae dispersion } \\
\text { factor } \beta\end{array}$ & $\begin{array}{l}\text { Larvae } \\
\text { mortality rate }\end{array}$ & $\begin{array}{l}\text { Larvae sinking } \\
\text { velocity }\end{array}$ & $\begin{array}{l}\text { Critical bottom strain } \\
\text { for larvae deposition }\end{array}$ & $\begin{array}{l}\text { Benthic } \\
\text { mortality rate }\end{array}$ \\
\hline $\mathrm{A}$ & 3.5 & 0.5 & $100 /\left(1+\mathrm{e}^{-0.6 \text {.age }+12)}\right.$ & 3 & $0.3+2.2 . \mathrm{e}^{-0.01 . \mathrm{W}}$ \\
\hline B & 7 & 0.7 & $100 /\left(1+\mathrm{e}^{-0.6 \text {.age }+12)}\right.$ & 3 & $0.3+2.2 \cdot \mathrm{e}^{-0.01 . \mathrm{w}}$ \\
\hline $\mathrm{C}$ & 7 & 0.3 & $100 /\left(1+\mathrm{e}^{-0.6 \text {.age }+12)}\right.$ & 3 & $0.3+2.2 \cdot \mathrm{e}^{-0.01 . \mathrm{w}}$ \\
\hline $\mathrm{D}$ & 7 & 0.5 & $\mathbf{5 0} /\left(1+\mathrm{e}^{-0.6 . \text { age }+12)}\right.$ & 3 & $0.3+2.2 \cdot \mathrm{e}^{-0.01 . \mathrm{W}}$ \\
\hline $\mathrm{E}$ & 7 & 0.5 & $100 /\left(1+\mathrm{e}^{-0.6 \text { age }+12)}\right.$ & 1.5 & $0.3+2.2 \cdot \mathrm{e}^{-0.01 . \mathrm{W}}$ \\
\hline $\mathrm{F}$ & 7 & 0.5 & $100 /\left(1+\mathrm{e}^{-0.6 . \mathrm{age}+12)}\right.$ & 3 & $0.3+2.2 \cdot \mathrm{e}^{-\mathbf{0 . 0 1 5} . \mathrm{W}}$ \\
\hline G & 7 & 0.5 & $100 /\left(1+\mathrm{e}^{-0.6 \text {.age }+12)}\right.$ & 3 & $0.3+2.2 . \mathrm{e}^{-0.007 . \mathrm{W}}$ \\
\hline
\end{tabular}

Table 5: Results of the sensitivity analysis (sensitivity index explained in the text).

\begin{tabular}{ll}
\hline Simulations & Sensitivity index \\
\hline A & 23 \\
B & 28 \\
C & 29 \\
D & 7 \\
E & 15 \\
F & 45 \\
G & 39 \\
\hline
\end{tabular}




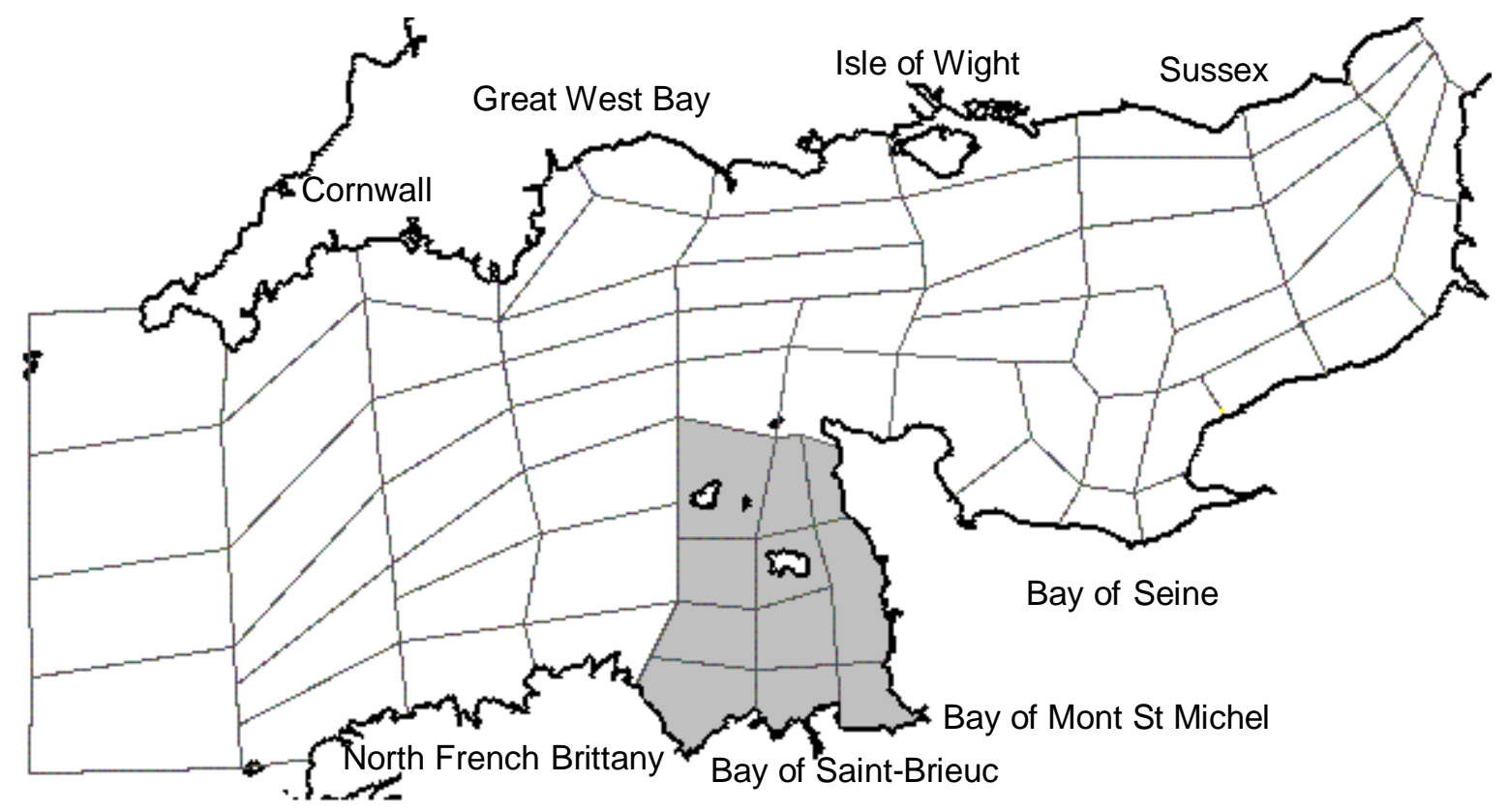

Fig. 1: The English Channel Sea and the box design. The grey area corresponds to the Golfe Normand Breton.

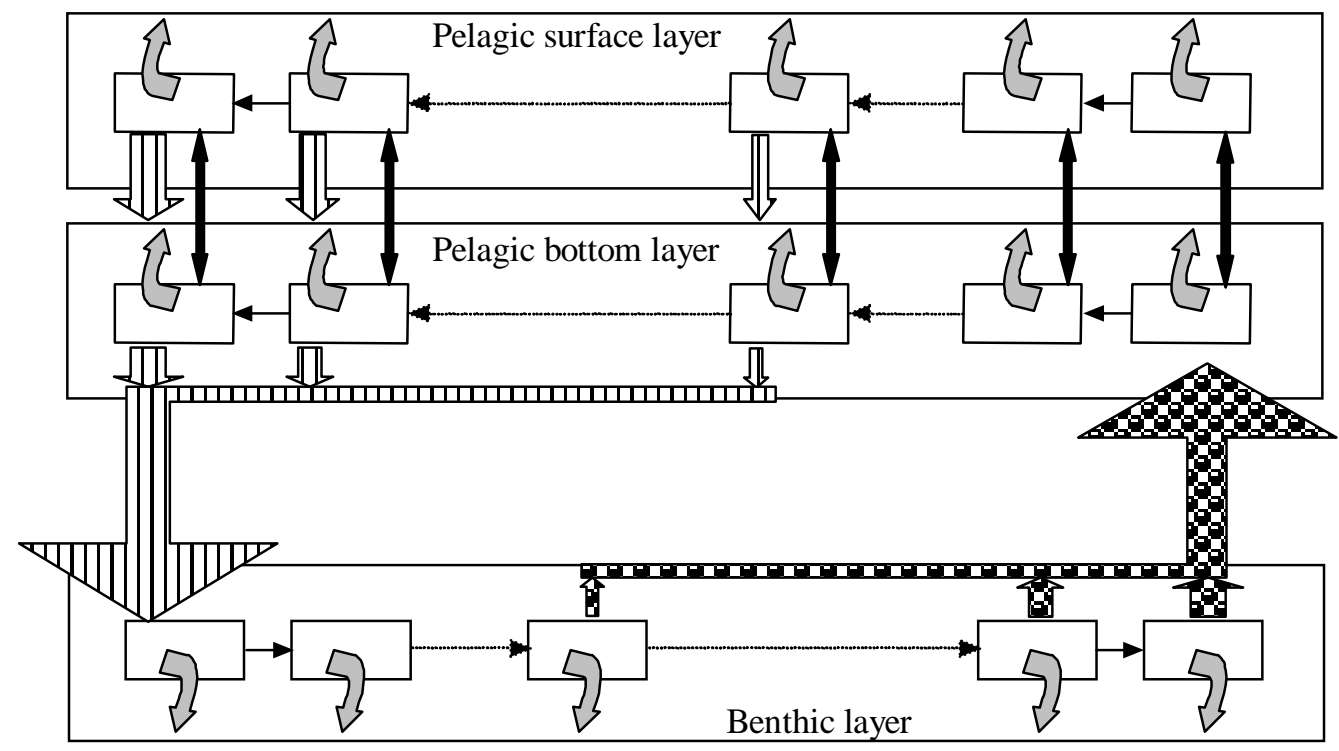

Fig. 2: Structure of the population dynamics model. 


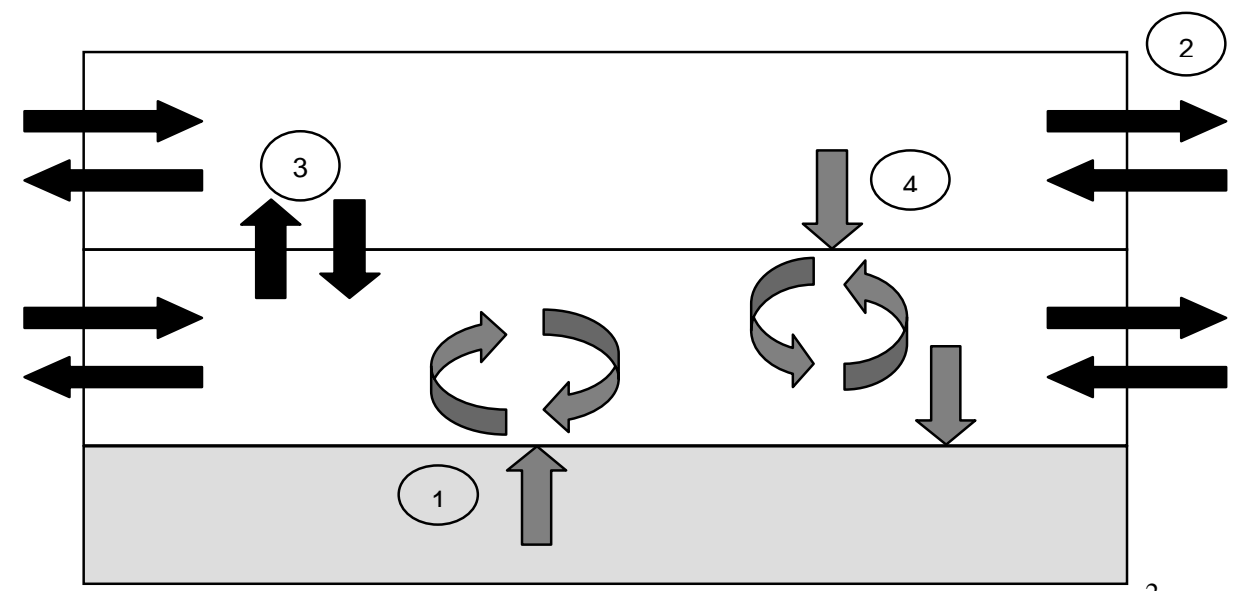

Fig. 3: Processes acting on the larval stages: (1) The spawned eggs (eggs. $\mathrm{m}^{-2}$ of substrate) are transferred into the first age class of larvae of the above water layer (larvae. $\left.\mathrm{m}^{-3}\right)$; (2) the larvae are advected-dispersed horizontally between boxes and (3) dispersed vertically between layers; (4) above a given age class, larvae start to settle: from the surface layer to the bottom layer, and from the bottom layer to the sediment layer. Sedimentation fluxes of larvae as well as gains of larvae in the sediment layer are expressed in ind. $\mathrm{m}^{-2} . \mathrm{j}^{-1}$, whereas loss or gains of larvae in the water layers are expressed in ind. $\mathrm{m}^{-3} \cdot \mathrm{j}^{-1}$, considering the water layer thickness.

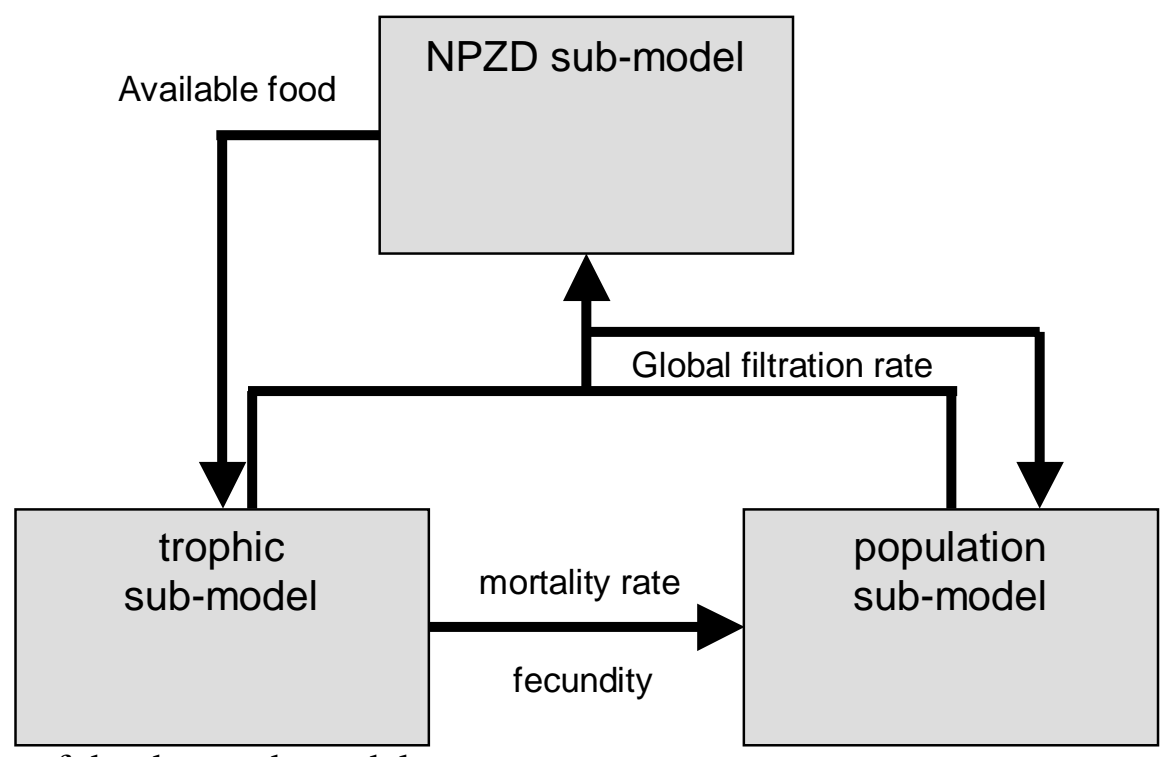

Fig. 4: Coupling of the three sub-models. 


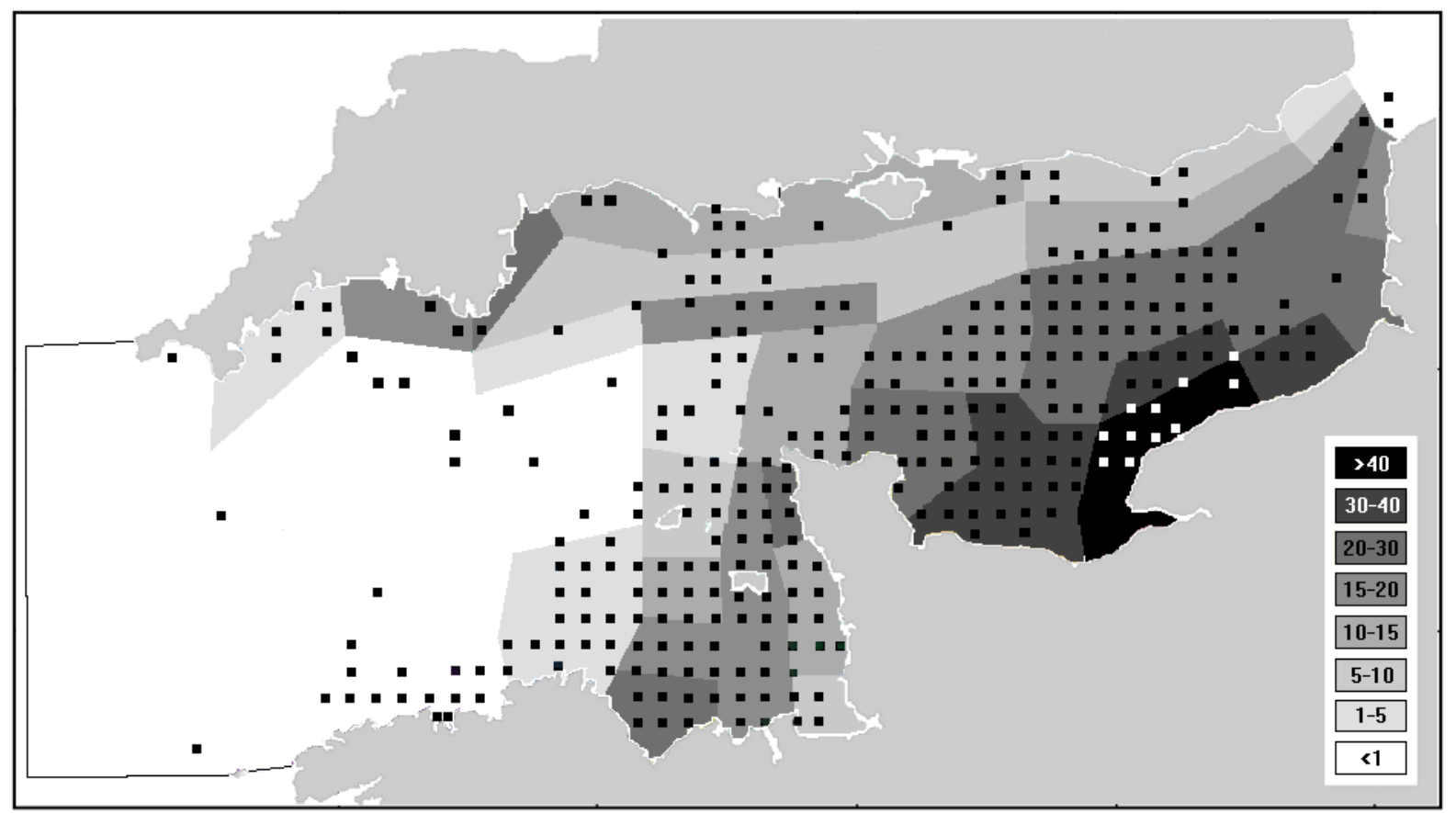

Fig. 5: Distribution of P. rhomboïdes in the whole Channel Sea. The gray levels indicate the steady state abundances (ind. $\mathrm{m}^{-2}$ of individuals aged of 2 years and more) obtained with the model, whereas the black squares indicate the actual occurrence of the species, as determined by Cabioch et al. (personal communication, 2002).

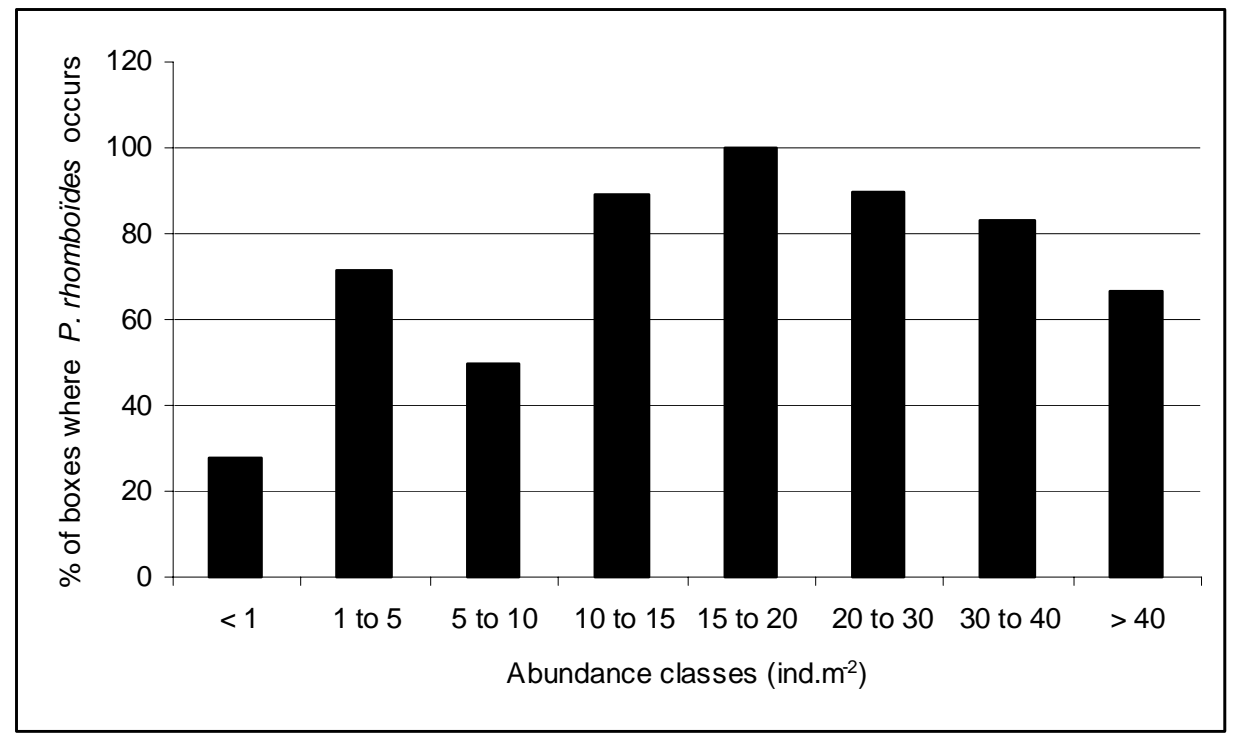

Fig. 6: Proportion of boxes where P. rhomboïdes occurs (compiled from Cabioch et al., personal communication, 2002) for each abundance class based on the steady state model results (Fig. 5). 


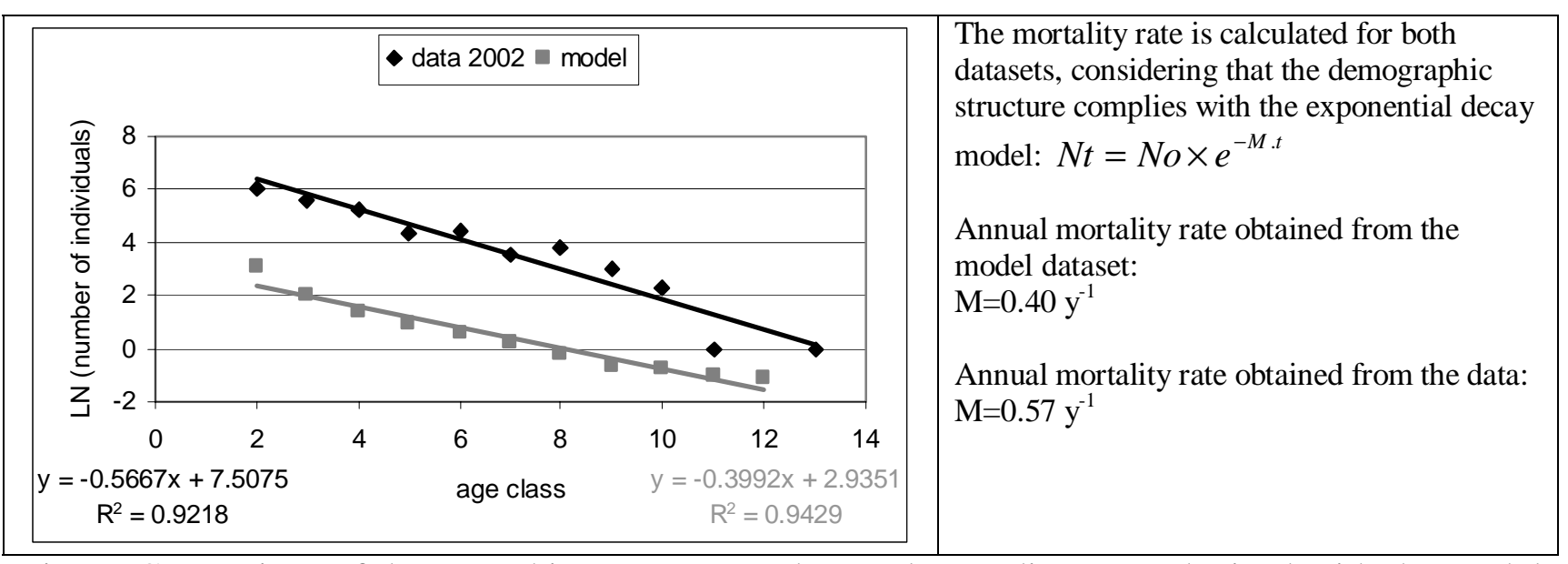

Fig. 7: Comparison of demographic structures and annual mortality rates obtained with the model and from data in the box Bay of Saint-Brieuc.

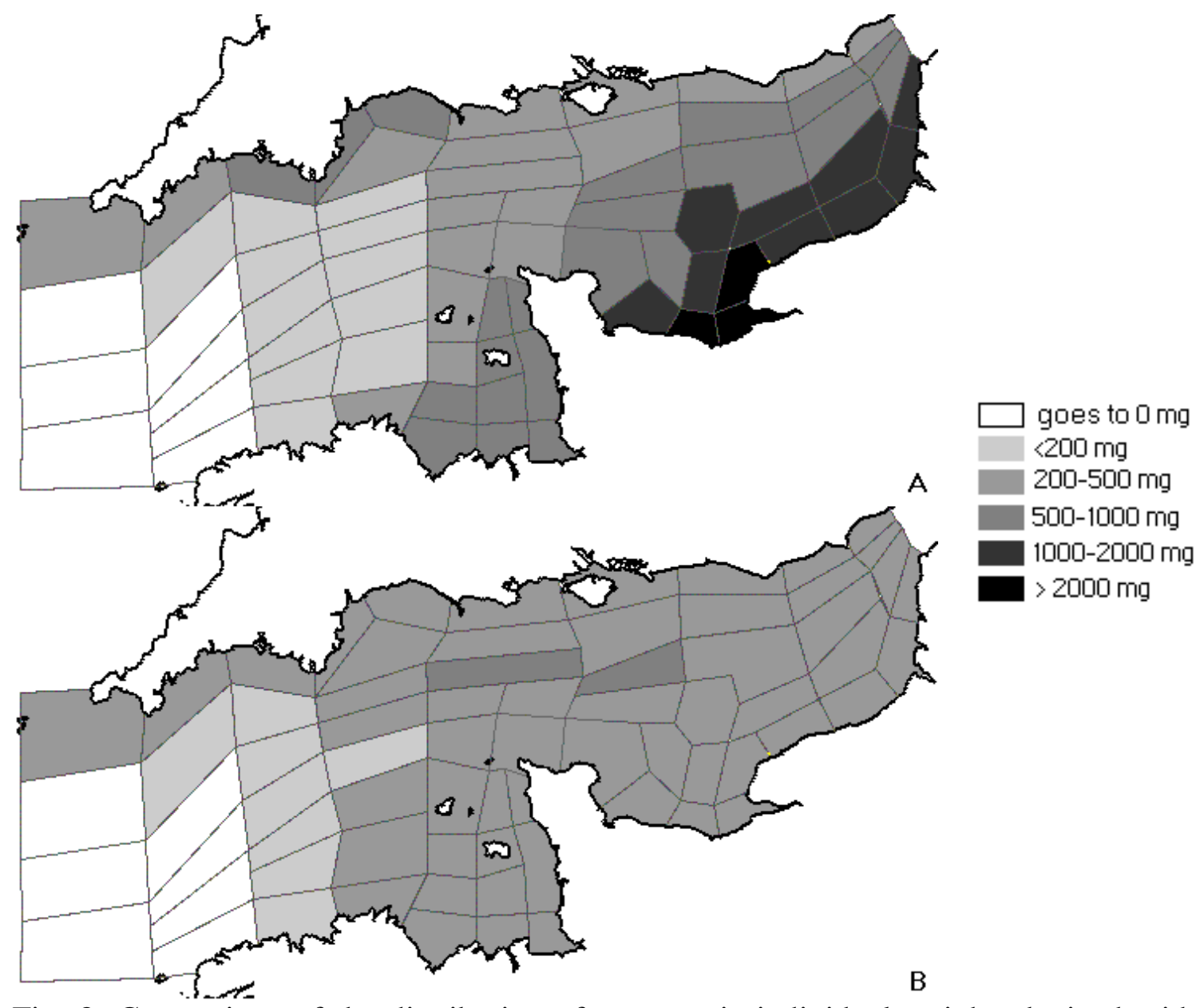

Fig. 8: Comparison of the distribution of asymptotic individual weight obtained with the forced growth model only (A, see Savina and Ménesguen, in press) and the fully coupled model (B). Each map corresponds to a classification of the boxes on the basis of the asymptotic individual weight. The map B shows the steady state of the model obtained for the nominal simulation. 


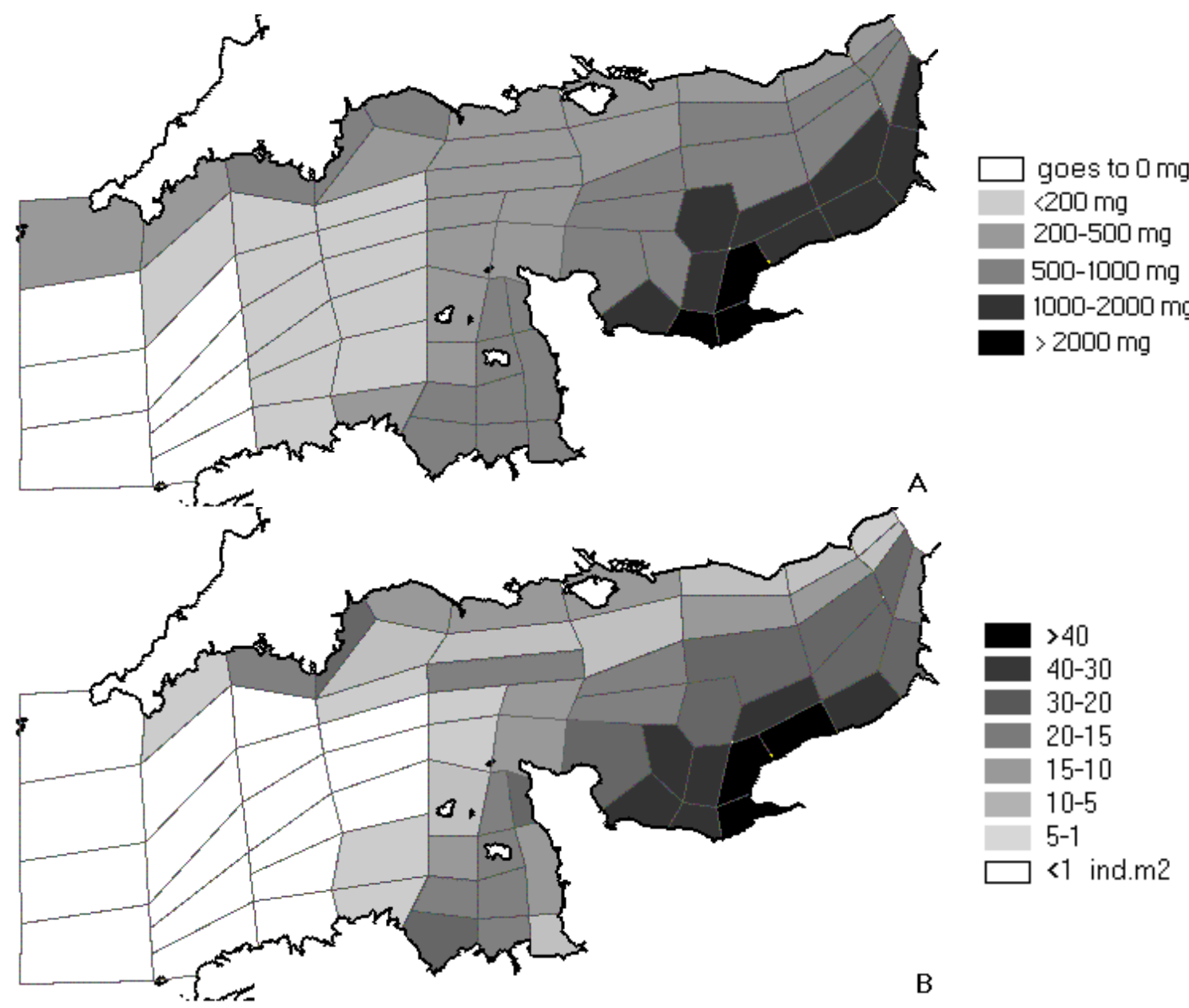

Fig. 9: Comparison of the distribution of asymptotic individual weight obtained with the simple growth model (A, see Savina and Menesguen, in press) and the population distribution obtained with the fully coupled model (B, steady state).

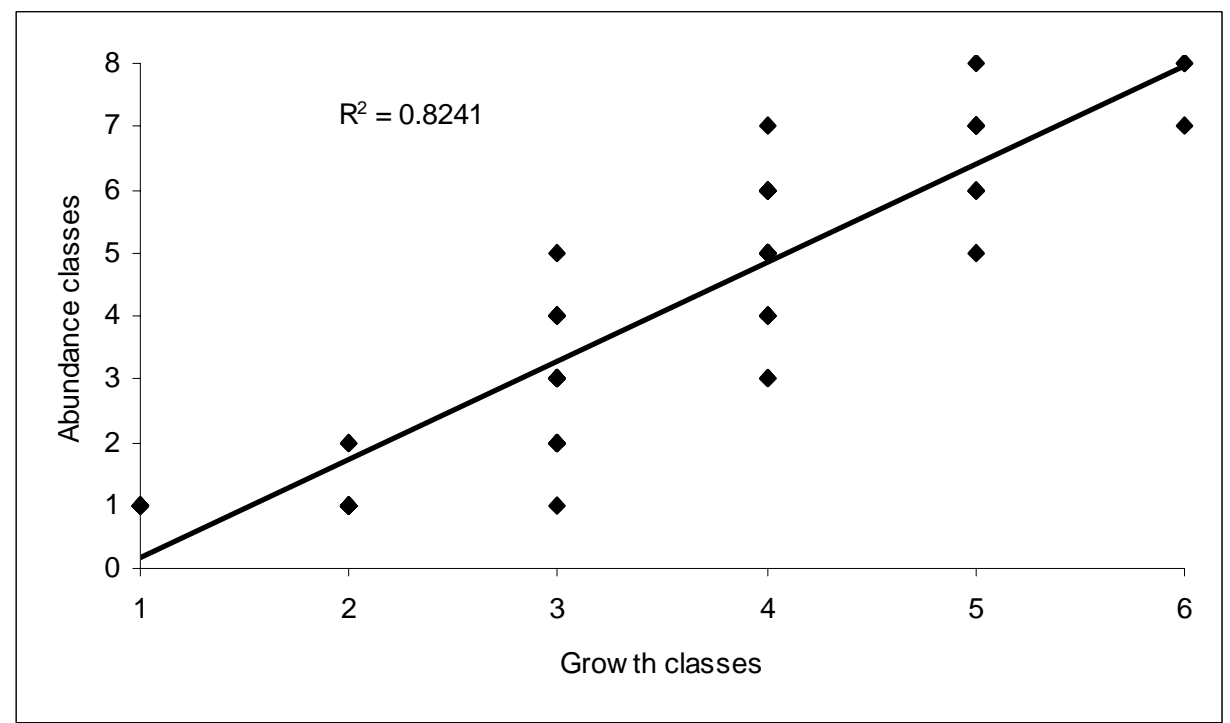

Fig. 10: Comparison between the abundances obtained with the fully coupled model (steady state, abundance classes: $<1,1-5,5-10,10-15,15-20,20-30,30-40,>40$ ind. $^{-2}$ ) and the asymptotical individual weights obtained with the growth model alone (Savina and Ménesguen, in press, growth class: asymptotic weight goes to $0,<200,200-500,500-1000,1000-2000,>2000 \mathrm{mg}$ ). 


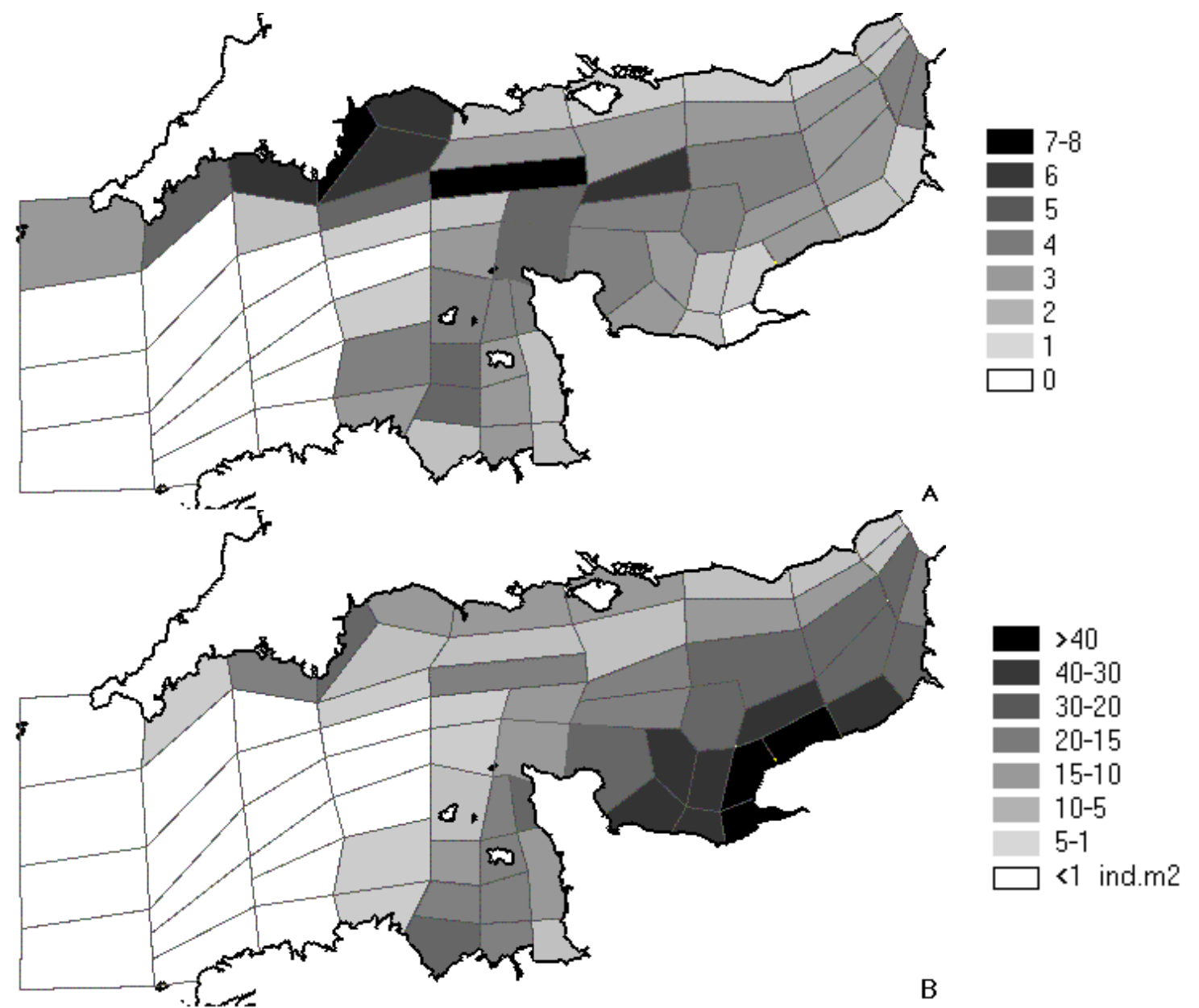

Fig. 11: Sensitivity analysis: the box sensitivity index (A, see text 2.2.4) compared to the bivalve abundance (B, nominal simulation, steady state). 